\title{
CYTOTOXIC EFFECTS OF HALOGENATED ANAESTHETICS ON CULTURED HUMAN LIVER AND EMBRYONIC KIDNEY CELLS
}

\author{
Guenter Corssen, M.D.*
}

There is CONTINUED CONCERN as to whether hepatic and kidney dysfunction may result from the use of halogenated anaesthetic agents. While clinical methods for evaluating possible hepatoxic or nephrotoxic effects of these agents may be hampered by lack of controls, experimental methods involving cultures of human liver and kidney cells have proved to be reliable means of analysis and assessment of toxic properties of drugs. With the aid of phase-contrast, time-lapse microcinematography, it is possible to observe and to record drug-induced morphologic cellular alterations involving nuclei, nucleoli, and cytoplasm as well as changes in cytoplasmic activity or pinocytosis.

For the study of possible hepatoxic properties of halogenated anaesthetics we employed human liver cells ${ }^{1}$ which were cultured in appropriate nutrient media (Figure 1). The cells were exposed to various concentrations of the three halogenated anaesthetics, chloroform, halothane, and methoxyflurane (Table). At clinically useful concentrations chloroform caused minimal and reversible cellular damage while with halothane and methoxyflurane disturbing effects on cell morphology and cytoplasmic function were virtually absent. Only in excessive concentrations did chloroform produce generalized and permanent cell damage. With halothane administered in excessive concentrations only some cells underwent distintegration and with methoxyflurane maximal saturation of the cultured medium failed to produce generalized damage.

These observations were made with cells cultured in a medium containing all essential nutrients necessary for uninhibited and unimpaired cell growth.

When the nutrient medium was rendered nutritionally deficient by removing either proteins or carbohydrates, it was found that the liver cells were considerably more susceptible to the potentially toxic effects of the halogenated anaesthetics. ${ }^{2}$ This was particularly true when the cultured medium was deprived of amino acids in which case halothane caused slight to moderate cell damage. Figure 2 shows the effect of halothane on the cultured cells growing in optimal culture medium. Figure 3 shows the effect of halothane perfused at the same strength as used in Figure 2 but with the cells growing in culture mediums deprived of amino acids.

With methoxyflurane, marked cell damage was recorded when the concentrations reached levels equivalent to deep surgical anaesthesia. In the amino acid-free culture medium, chloroform produced severe cell damage at a concentration as low as half of that found in the hepatovenous circulation of laboratory animals during surgical anaesthesia. When the concentration of chloroform was increased to the

*Birmingham, Alabama. 


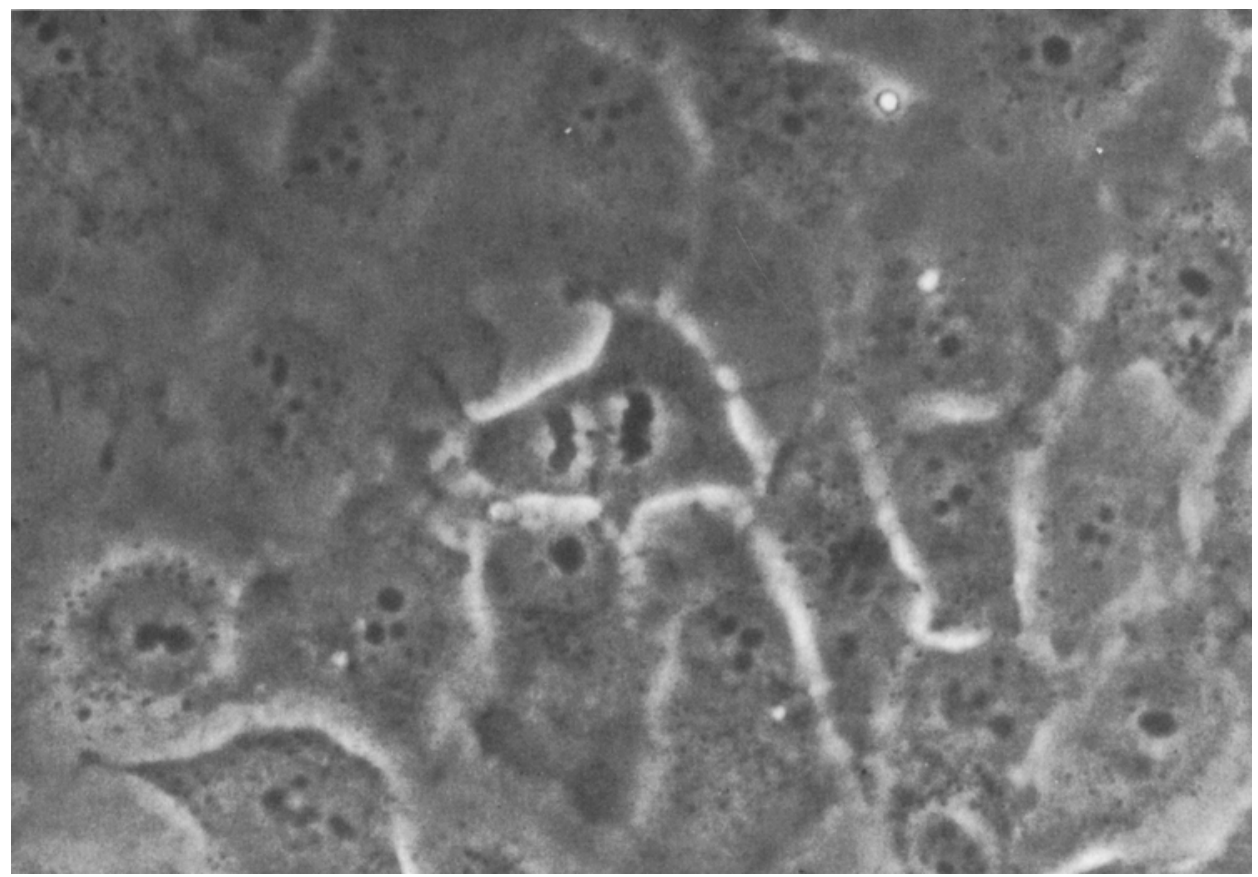

Figure 1. Human liver cells (Chang) growing in complete culture medium.

TABLE

Concentrations of Chloroform, Halothane, and Methoxyflurane in Culture Medium and Corresponding Levels of Anaesthesia

\begin{tabular}{lcl}
\hline \multicolumn{1}{c}{ Agent } & $\begin{array}{c}\text { Concentration } \\
\text { mg. per } 100 \mathrm{ml}\end{array}$ & $\begin{array}{c}\text { Corresponding level of } \\
\text { anaesthesia }\end{array}$ \\
\hline Chloroform & 15.0 & Not determined \\
Halothane & 29.0 & Surgical anaesthesia \\
Methoxyflurane & 31.3 & Light surgical anaesthesia \\
& 52.2 & Deep surgical anaesthesia \\
& 30.7 & Light surgical anaesthesia \\
& 75.2 & Deep surgical anaesthesia \\
\hline
\end{tabular}

full strength of that found in the blood during surgical anaesthesia, profound and generalized cell damage prevailed.

With the glucose-free culture medium, a clear-cut increase in the vulnerability of the cells was seen only with chloroform, while there was little difference in the appearance of the cells exposed to halothane or methoxyflurane whether they were cultured in the control medium or in the glucose-free medium.

The degree of cellular damage correlated closely with the functional behaviour of the cells as interpreted by the analysis of time-lapse cinematography. Cytoplasmic activity consisting of rhythmical protrusion and contraction of the cell membranes, was decreased and sometimes even arrested when chloroform was perfused 


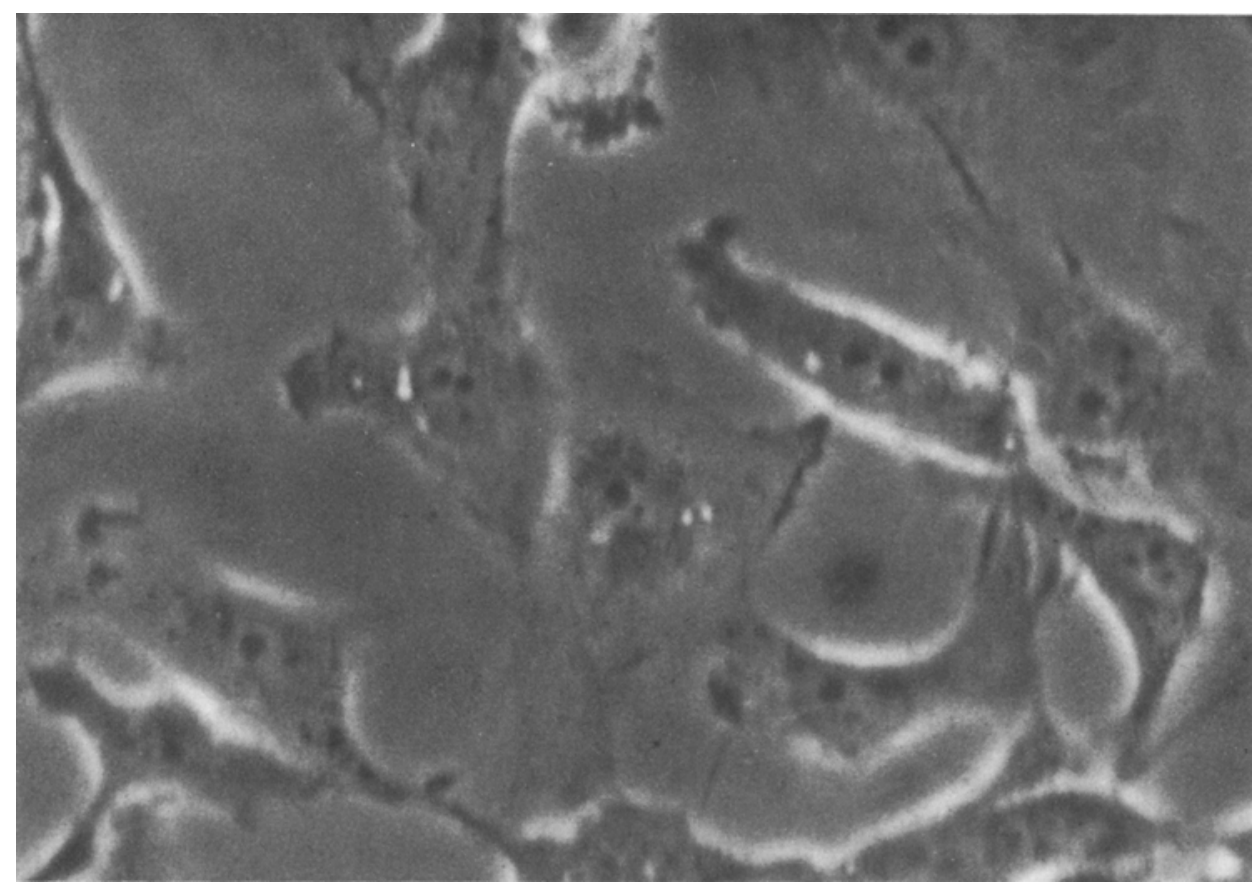

Figure 2. Human liver cells growing in complete culture medium exposed to halothane ( 52 $\mathrm{mg} / 100 \mathrm{ml}$ ) for 72 hours. No noticeable cell damage. Magnification: $\times 665$; reduced 30 per cent.

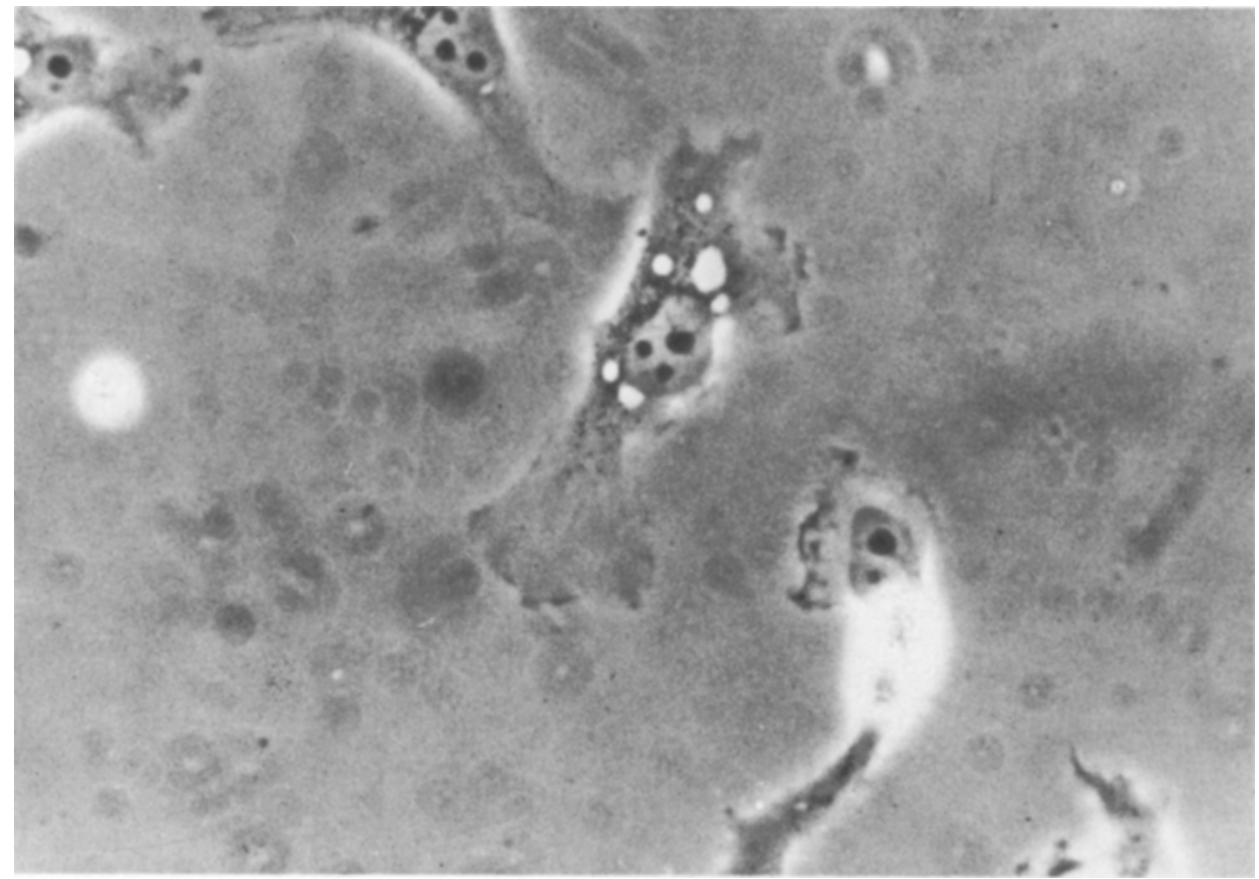

Figure 3. Human liver cells growing in amino acid-free culture medium after 24 hours' exposure to halothane $(52 \mathrm{mg} / 100 \mathrm{ml})$. Note: Cell on the right side has disintegrated. Accumulation of intracytoplasmic vacuoles in cell in center. Magnification: $\times 830$; reduced 30 per cent. 


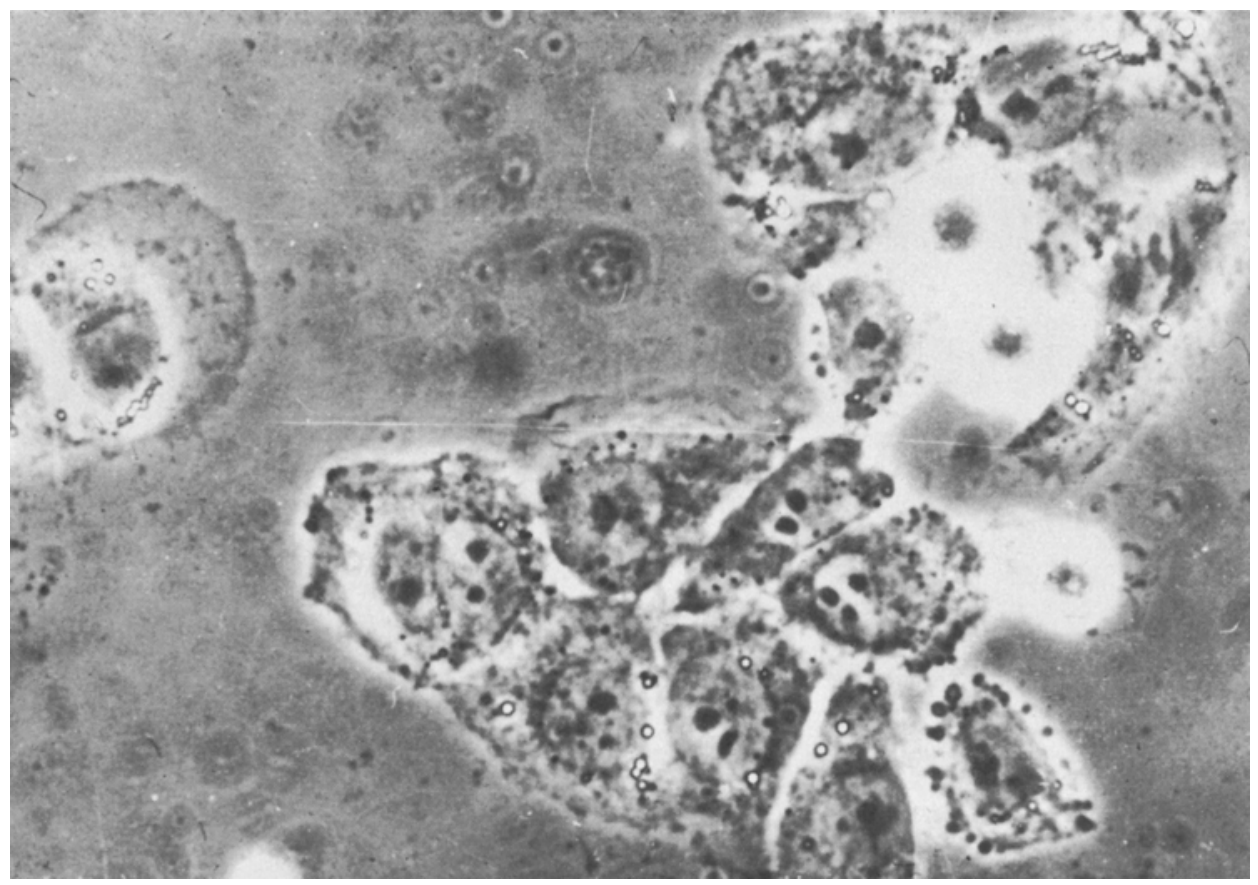

Figure 4. Photomicrograph of human embryonic kidney cells in perfusion chamber. Note mitoses (arrows) in various phases. $\times 830$.

through the amino acid-free culture medium. In the same medium, methoxyflurane and halothane perfusion resulted in slowing in membranous activity in concentrations resembling deep surgical anaesthesia. In the glucose-free medium, the functional behaviour of the cells was only insignificantly curtailed with the perfusion of chloroform in concentrations resembling deep surgical anaesthesia. There appeared very little impairment of cytoplasmic movement with either methoxyflurane or halothane.

For the study of possible nephrotoxic properties of methoxyflurane and other halogenated anaesthetics we used cultures of human embryonic kidney cells. ${ }^{3}$ This cell strain seemed particularly suitable since the cells rapidly divided and subdivided when they were kept in optimal nutrient culture media. In fact, the mitotic activity was so pronounced that it could serve as an index of cellular function. Reduction of the speed of cell division or cessation of mitosis with or without morphological changes could be interpreted as a reflection of the cytotoxic effects of the halogenated anaesthetics to which the cells were exposed.

After a baseline rate of growth was established in the perfusion chamber, the nutrient medium was replaced by a medium containing either chloroform, halothane or methoxyflurane. The concentrations of the three agents in the culture medium were equal to those reported for the venous-hepatic circulation in laboratory animals at various levels of surgical anaesthesia.

The following observations were made: Halothane and methoxyflurane (Figure 4) did not result in cellular injury nor was the functional behaviour of the cells altered or the cytoplasmic function or mitotic activity affected. Only when halo- 


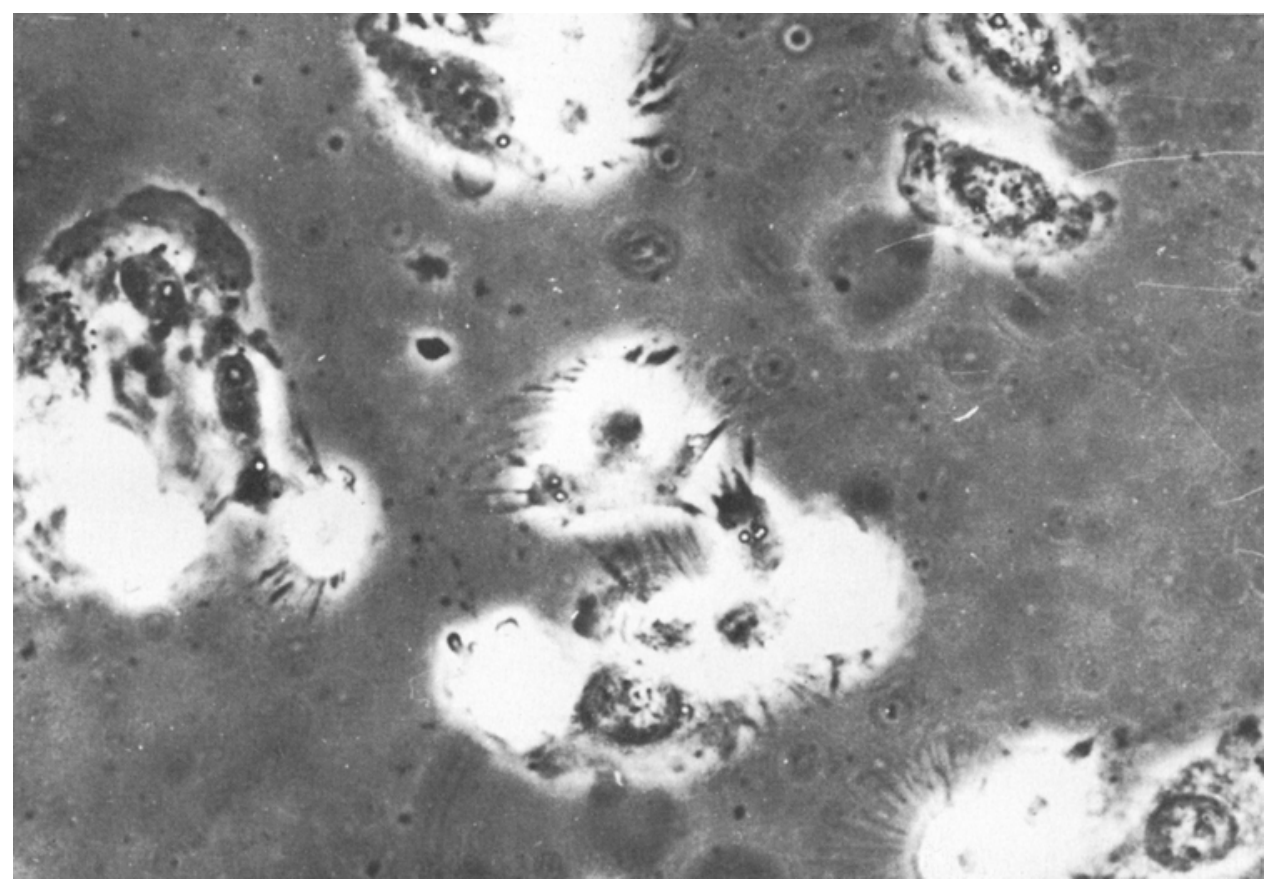

Figure 5. Group of embryonic kidney cells after exposure for 1 hour to methoxyflurane (75.2 $\mathrm{mg} / 100 \mathrm{ml}$ ) containing traces of halothane. Note that cells in various phases of mitosis have lost their smooth, round appearance (large arrows), with threadlike arrangement of cytoplasm and cessation of membranous movements. In some of the older cells, the cytoplasm has assumed a bulblike appearance and the nuclei and nucleoli have disappeared (small arrows).

thane was perfused over prolonged periods was minimal impairment of cell function observed. Chloroform perfused over similar periods (up to 40 hours) caused injury to cells and significant functional impairment. A surprising finding was that the methoxyflurane vapor was rendered cytotoxic when the copper kettle vaporizer contained traces of contaminants possibly including halothane (Figure 5). It is possible that the toxic effects of contaminated methoxyflurane were the result of a breakdown of the residual halothane when the drug was stored in the vaporizer during relatively long periods.

Until the mechanisms by which methoxyflurane may be rendered toxic is better understood it is reasonable to assume that meticulous procedures for cleansing and storing equipment will effectively guard against this hazard in clinical practice.

\section{RÉSUMÉ}

Pour l'étude des propriétés hépatotoxiques possibles des agents anesthésiques halogénés, nous avons employé des cellules hépatiques humaines, cultivées dans un milieu nutritif approprié. Les cellules étaient exposées à des concentrations cliniques variés des trois substances anesthésiques halogěnées : chloroforme - halothane - et méthoxyflurane. Le chloroforme produisit un dommage cellulaire minime et réversible, tandis que les troubles sur la morphologie cellulaire et la fonc- 
tion cytoplasmique causés par l'halothane ou le méthoxyflurane étaient vertuellement absent. Seulement qu'en concentration excessive, le chloroforme a produit des dommages cellulaires permanents et généralisés. Avec l'halothane en concentration excessive seulement quelques cellules affichèrent une désintégration. Quant au méthoxyflurane à saturation maximale du milieu de culture on n'observe point de dommage généralisé.

Ces observations ont été faite sur des cellules cultivées dans un milieu contenant toutes les substances nutritives nécessaires pour la croissance cellulaire normale.

Quand le milieu nutritif était rendu déficient nutritionellement en le privant de protéines, ou d'hydrate de carbone, les cellules hépatiques affichaient une susceptibilité plus marquée aux effets potentiellement toxiques des anesthésiques halogénés. Ceci était particulièrement vrai quand le milieu de culture était dépourvu d'acides aminés, auquel cas l'halothane produisit des dommages cellulaires variant de la forme légère à forme modérée. Avec le méthoxyflurane des dommages cellulaires marqués ont été notés quand les niveaux équivalaient à une anesthésie chirurgicale profonde. Dans le milieu de culture dépourvu d'acide aminé le chloroforme produisit des dommages cellulaires sévères à une concentration aussi basse que la moitié de celle trouvée dans la circulation veineuse hépatique d'animaux de laboratoire sous anesthésie chirurgicale. Des dommages cellulaires profonds et généralisés ont été mis en évidence.

Avec le milieu de culture dépourvu de glucose, une accentuation nette dans la vulnérabilité des cellules a été constatée seulement avec le chloroforme, tandis que les cellules traitées au méthoxyflurane ou au fluothane présentaient peu de différence dans leur apparence, qu'elles fussent traités dans le milieu de controle ou un milieu dépourvu de glucose.

Pour l'étude des propriétés néphrotoxiques possibles du méthoxyflurane, et d'autres agents anesthésiques halogénés, nous avons utilisé des cultures de cellule rénale embryonnaire qui se divisent et se redivisent rapidement quand elles étaient tenues dans des milieux de culture de nutrition optima. En fait, l'activité métoxique était si prononcée qu'elle pourrait servir d'index de la fonction cellulaire. Toute réduction dans le système de division cellulaire ou toute cessation de mitose avec ou sans changement morphologique peuvent être interprétés comme une conséquence des effets cytotoxiques des anesthésiques halogénés auxquelles les cellules furent séparés.

Après avoir établi un rythme de croissance de base dans la chambre de perfusion, le milieu nutritif a été remplacé par un autre contenant soit le chloroforme soit l'halothane ou le méthoxyflurane. La concentration des trois agents dans le milieu de culture était égale à celle rapportée dans la circulation hépatique veineuse des animaux de laboratoire à différent niveaux d'anesthésie chirurgicale.

Les observations suivantes ont été faites : l'halothane et le méthoxyflurane ne produisent pas de trouble cellulaire, d'altération cellulaire fonctionnelle, de modification cystoplasmique, ou d'affection de l'activité métodique. Seulement quand le méthoxyflurane était perfusé sur une période prolongée, des modifications minimes de la fonction cellulaire étaient observées. Le chloroforme en infusion devant cette même période (au dessus de 40 heures) produisit des dommages cellulaires et des altérations fonctionnelles significatives. Une observation surprenante fut 
que les vapeurs de méthoxyflurane ont été trouvées cytotoxiques quand le "Copper Kettle" vaporisateur, contenait des traces de contaminisants, fluothane y compris. Il est possible que les effets toxiques du méthoxyflurane contaminé ont été le résultat de la décomposition du fluothane résiduel quand l'agent a été conservé durant une période trop longue dans le vaporisateur.

Jusquà ce que les mécanismes par lesquels le méthoxyflurane peut être rendu toxique soient mieux compris, il est raisonnable d'avancer que des procédés méticuleux pour le nettoyage et l'entreposage de l'équipement utilisé pourra protéger contre cette éventualité en pratique clinique.

\section{REFERENCES}

1. Conssen, G., Sweet, R.B., \& Chenoweth, M.B. Effects of chloroform, halothane and methoxyfluorane on human liver cells in vitro. Anesthesiology 27: 155-162 (Mar.-Apr.), 1966.

2. Corssen, G. \& Sweer, R.B. Effects of halogenated anesthetic agents on selectively starved cultured human liver cells. Anesthesia \& Analgesia ... Current Researches 46: 575-588 (Sept.-Oct.) 1967.

3. Corrsen, G. Effects of halogenated anesthetic agents on human embryonic kidney cells. Anesthesia \& Analgesia ... Current Researches 48: 858-867 (Sept.-Oct.) 1969. 